\title{
25. BIOGENIC CARBONATE PRODUCTION AND PRESERVATION CHANGES BETWEEN 5 AND 10 MA FROM THE CEARA RISE, WESTERN EQUATORIAL ATLANTIC ${ }^{1}$
}

\author{
D.W. Murray ${ }^{2}$ and L.C. Peterson ${ }^{3}$
}

\begin{abstract}
This study presents carbonate concentration, accumulation, and preservation data for the middle to late Miocene $(\sim 5-10$ $\mathrm{Ma})$ to examine changes in carbonate sedimentation associated with surface productivity and dissolution at the Ceara Rise in the western equatorial Atlantic. Time series of magnetic susceptibility-based estimates of calcium carbonate concentration for Ceara Rise Sites 925, 928, and 929, which together form a transect that spans approximately $1500 \mathrm{~m}$ of water depth (3041$4356 \mathrm{~m}$ ), show substantial changes in the depth gradient of calcium carbonate concentration between 5 and $10 \mathrm{Ma}$. The estimated carbonate concentrations at the shallow Site 925 were relatively high $(\overline{\mathrm{x}}=77.2 \%)$ throughout this whole time interval. Prior to about 5.5 Ma, only trace amounts of carbonate are preserved at the deep Site 929, indicating that the carbonate compensation depth (CCD) was close to or shallower than the depth of this site during most of the middle to late Miocene. To further examine these gradients, we generated carbonate concentration, accumulation, and foraminiferal preservation data for four representative time slices from Sites 925,928 , and 929.

The results show that, during the late Miocene, the quasi-cyclic changes in carbonate concentration at shallow Site 925 can be attributed to either production or dilution by terrigenous material, depending on the interval. Calcium carbonate sedimentation at Site 925 averaged $>20 \mathrm{~g} / \mathrm{m}^{2} / \mathrm{yr}$, more than twice the Holocene rates. The foraminiferal assemblage was extremely well preserved, and the sediment fluxes reflect carbonate rain rates to the seafloor. These high accumulation rates are comparable to the highest sediment trap-measured fluxes of carbonate from the equatorial Pacific. In contrast, calcium carbonate at the deep sites is heavily dissolved and dissolution was the dominant control of concentration changes. This decrease reflects a shoaling of the CCD, which coincides with a period of sea level rise. The results are not consistent with an increase of North Atlantic Deep Water (NADW) during the late Miocene, although further work is necessary to evaluate the relative contributions of NADW and southern component water at this site.
\end{abstract}

\section{INTRODUCTION}

One of the primary objectives of Ocean Drilling Program (ODP) Leg 154 was to recover sediments from a depth transect of sites down the Ceara Rise to study deep-water chemistry and circulation changes in the tropical Atlantic. Located in the main flow path of the two major deep-water masses in the Atlantic Ocean, North Atlantic Deep Water (NADW) and Antarctic Bottom Water (AABW), the Ceara Rise is ideally situated to record variations in the mixing of these water masses that produce the chemical and physical characteristics of deep waters in the world's oceans today. The present mixing zone between NADW and AABW in the western equatorial Atlantic lies between 4000 and $4500 \mathrm{~m}$ water depth. Thus, the three shallow sites cored during ODP Leg 154, Sites 925, 926, and 927, are from locations presently bathed by NADW. Site 928 is within the mixing zone and Site 929 is bathed by AABW (Curry, Shackleton, Richter, et al., 1995). Studies have shown glacial to interglacial changes in the relative proportion and mixing of the deep waters in the Atlantic (e.g., Oppo and Fairbanks, 1987; Curry et al., 1988; Charles and Fairbanks, 1992). During the last glaciation, there was a greater proportion of Southern Ocean deep water at the Ceara Rise. Associated with this increase in the more corrosive Southern Ocean water during the glacial was a significant increase in carbonate dissolution at sites below 4000 $m$ in the western Atlantic (Curry and Lohmann, 1990). On longer time scales, such changes in dissolution should also have occurred.

'Shackleton, N.J., Curry, W.B., Richter, C., and Bralower, T.J. (Eds.), 1997. Proc. ODP, Sci. Results, 154: College Station, TX (Ocean Drilling Program).

${ }^{2}$ Department of Geological Sciences, Brown University, Providence, RI, 02912 U.S.A.dmurray@brown.edu

${ }^{3}$ Rosenstiel School of Marine and Atmospheric Science, University of Miami, Miami, FL 33149, U.S.A.
Preliminary shipboard data for the 5- to 15 -Ma interval show that carbonate accumulation at the deeper sites was $60 \%-100 \%$ lower than at the shallower sites (Shipboard Scientific Party, 1995a). This high loss of carbonate with depth reflects a shoaling of the carbonate compensation depth (CCD) close to the depth of Site 928 (currently $4012 \mathrm{~m}$ ) compared to preceding and following time intervals. For comparison, the present CCD is below $4600 \mathrm{~m}$ for the modern and last glacial interval (Curry and Lohmann, 1990). A shoaling of the $\mathrm{CCD}$ is also observed in the late Miocene in the equatorial Indian and Pacific Oceans (ODP Leg 115, Peterson and Backman, 1990; ODP Leg 130, Berger et al., 1993). In contrast, mean carbonate accumulation rates during the late Miocene and early Pliocene at the shallow sites on the Ceara Rise were at least twice the modern rates (Shipboard Scientific Party, 1995a). Between 5 and 7 Ma, similar increases in calcium carbonate accumulation have been observed in all the major oceans and have been attributed to an increase in surface production (Peterson et al., 1992; Berger et al., 1993; Dickens and Owen, 1994; Farrell et al., 1995). Berger et al. (1993) called upon an increase in the production of NADW as being responsible for the changes observed in the Pacific. Berger et al. (1993) note that this "modulator" of carbonate sedimentation would cause a PacificAtlantic asymmetry. The preliminary data on carbonate accumulation in the late Miocene from the Ceara Rise (Curry, Shackleton, Richter, et al., 1995) indicate that this asymmetry did not exist, and the records from the equatorial Pacific, Indian, and Atlantic Oceans all show similar shallow to deep patterns of accumulation.

Because the shipboard results provide only a coarse view of the calcium carbonate variations, the goal of this study is to examine the Atlantic pattern between 5 and $10 \mathrm{Ma}$ in greater detail. Four discrete time intervals that represent different $\mathrm{CaCO}_{3}$ concentration gradients at the Ceara Rise were sampled in sufficient detail to resolve orbitalscale variations. Data on carbonate concentration, accumulation, and 
preservation are used to decipher variations attributed to $\mathrm{CaCO}_{3}$ production, dissolution, and dilution. These data from the western tropical Atlantic will be compared with gradients of carbonate accumulation from other oceanic sites to provide a broader perspective of deep sea carbonate changes in the late Miocene and to evaluate the proposed basin-to-basin fractionation model (Berger et al., 1993).

\section{METHODS}

Between 5 and $10 \mathrm{Ma}$, four time slices of approximately $400 \mathrm{k} . \mathrm{y}$. in length were sampled at 10-cm intervals from ODP Sites 925 and 928 on the Ceara Rise (Fig. 1). The selected time intervals, 5.0-5.4, 6.0-6.4, 8.0-8.4, and 9.6-10.0 Ma, were chosen to reflect variations in the depth gradient of $\mathrm{CaCO}_{3}$ concentrations observed in the late Miocene (Curry, Shackleton, Richter, et al., 1995). The 5.0-5.4 Ma time interval was also sampled at Site 929. Sediments in the three older time intervals at Site 929 consisted of either trace amounts of carbonate material or contorted sediments thought to be redeposited, slumped material (Shipboard Scientific Party, 1995c).

The $10-\mathrm{cm}^{3}$ samples were taken from multiple holes at the sites following the composite section developed during Leg 154 (Curry, Shackleton, Richter, et al., 1995). Preliminary ages based on biostratigraphy (Curry, Shackleton, Richter, et al., 1995) were used to guide the sampling. All samples were freeze-dried, then split in half. One-half was weighed, disaggregated in tap water, wet-sieved through a $63-\mu \mathrm{m}$ sieve, and dried at $50^{\circ} \mathrm{C}$. The fine fraction $(<63 \mu \mathrm{m})$ was dried and stored for future studies. The coarse fraction $(>63 \mu \mathrm{m})$ was weighed and dry-sieved at $150 \mu \mathrm{m}$. The $>150 \mu \mathrm{m}$ portion was weighed and divided equally into two aliquots, one for the study of faunal preservation (this study) and the other for stable isotope analysis at the University of Miami.

The faunal aliquot work was subdivided to obtain a representative sample of approximately 400 whole planktonic foraminifers. The number of whole planktonic foraminifers, planktonic fragments, benthic foraminifers, and radiolarians were tabulated for each sam- ple. In some Site 928 and 929 samples where fragmentation was substantial, small splits with 50-100 whole foraminifers were used to obtain the preservation data. Benthics were relatively rare, generally less than five in samples having 400 whole planktonic foraminifers. Only one or two radiolarians were observed in all the samples examined, confirming the lack of biogenic opal in these sediments. In addition to the weight percentage in the sand $(>63 \mu \mathrm{m})$ fraction, we used the following equation as an index of carbonate preservation:

whole planktonic foraminifers $(\%)=100 \times \#$ whole planktonic foraminifers $>150 \mu \mathrm{m} /$ (\# whole planktonic foraminifers $>150$ $\mu \mathrm{m}+$ \# planktonic fragments $>150 \mu \mathrm{m})$.

One-third of the remaining unprocessed sample was ground with a mortar and pestle and used to determine $\mathrm{CaCO}_{3}$ concentration. The calcium carbonate content of dried samples was measured on an automated, computer-controlled carbonate rig developed at Brown University and similar to the one described by Ostermann et al. (1990). Approximately $10 \mathrm{mg}$ of sample were reacted in $100 \%$ phosphoric acid at a constant temperature of $70^{\circ} \mathrm{C}$ in an evacuated, closed system. The pressure of the gas evolved from the reaction was measured on a pressure transducer. This pressure was converted to $\% \mathrm{CaCO}_{3}$ using a linear regression model based on five to six aliquots of a $100 \%$ carbonate standard in each run with weights ranging from 3 to $12 \mathrm{mg}$. Precision of the standards was better than $1 \%$. The mean difference of replicates on 103 samples in this study is $3.3 \%$ with a standard deviation of $3.5 \%$. Because of the longer reaction time needed for samples with a high clay content, we used a reaction time of $30 \mathrm{~min}$ for samples $<50 \% \mathrm{CaCO}_{3}$ and $10 \mathrm{~min}$ for samples $>50 \% \mathrm{CaCO}_{3}$. Pressure readings at 1-min intervals for the 10-min runs and 3-min intervals for the 30-min runs were retained for each sample to monitor the reaction.

Twenty-five of the shipboard carbonate samples from Sites 925 , 928, and 929 spanning the late Miocene were analyzed for carbonate content using the Brown Rig (Table 1). A comparison with analyses made during Leg 154 using a Coulometer (Curry, Shackleton, Rich-
Figure 1. Location map for Sites $925\left(4^{\circ} 12.3^{\prime} \mathrm{N}\right.$, $43^{\circ} 29.3^{\prime} \mathrm{W}, 3041 \mathrm{~m}$ water depth), $928\left(5^{\circ} 27.3^{\prime} \mathrm{N}\right.$, $43^{\circ} 44.9^{\prime} \mathrm{W}, 4012 \mathrm{~m}$ water depth), and $929\left(5^{\circ} 58.6^{\prime} \mathrm{N}\right.$, $43^{\circ} 44.4^{\prime} \mathrm{W}, 4356 \mathrm{~m}$ water depth). The map is modified from Curry, Shackleton, Richter, et al. (1995). Bathymetry in meters with a contour interval of $500 \mathrm{~m}$.

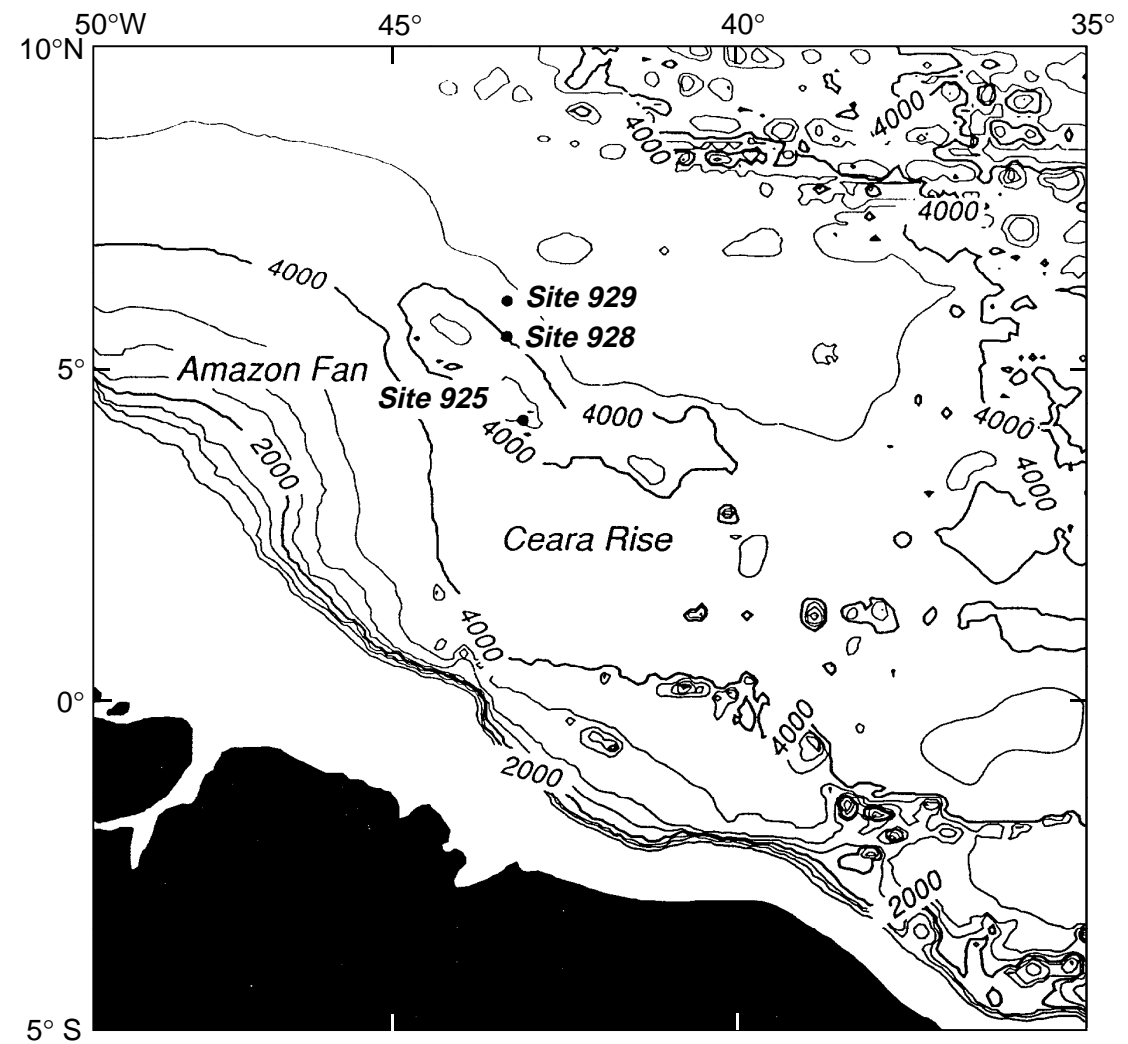


Table 1. Carbonate comparison of shipboard Coulometer and Brown automated rig measurements.

\begin{tabular}{|c|c|c|c|c|}
\hline $\begin{array}{l}\text { Core, section, } \\
\text { interval }(\mathrm{cm})^{\mathrm{a}}\end{array}$ & $\begin{array}{c}\mathrm{CaCO}_{3}(\%) \\
\text { Coulometer }\end{array}$ & $\begin{array}{c}\mathrm{CaCO}_{3}(\%) \\
\text { Brown Rig-1 }{ }^{\mathrm{c}}\end{array}$ & $\begin{array}{c}\mathrm{CaCO}_{3}(\%) \\
\text { Brown Rig-2 }\end{array}$ & $\begin{array}{c}\mathrm{CaCO}_{3}(\%) \\
\text { Mag. estimate }\end{array}$ \\
\hline $\begin{array}{c}154-925 \mathrm{~B}- \\
15 \mathrm{H}-3,77 \\
16 \mathrm{H}-3,115 \\
17 \mathrm{H}-3,69 \\
18 \mathrm{H}-3,106 \\
19 \mathrm{H}-3,132 \\
20 \mathrm{H}-3,90 \\
21 \mathrm{H}-3,135 \\
22 \mathrm{H}-3,50 \\
23 \mathrm{H}-3,33 \\
24 \mathrm{H}-3,97 \\
25 \mathrm{H}-3,100 \\
26 \mathrm{H}-3,116 \\
27 \mathrm{H}-3,130 \\
28 \mathrm{H}-3,56\end{array}$ & $\begin{array}{l}85.6 \\
69.6 \\
66.8 \\
74.6 \\
75.0 \\
83.6 \\
72.8 \\
68.1 \\
59.7 \\
78.4 \\
66.7 \\
81.0 \\
50.7 \\
80.7\end{array}$ & $\begin{array}{l}89.0 \\
71.6 \\
68.5 \\
75.8 \\
78.1 \\
85.9 \\
75.0 \\
70.5 \\
60.6 \\
83.0 \\
69.5 \\
74.5 \\
52.8 \\
79.0\end{array}$ & $\begin{array}{l}92.7 \\
74.2 \\
70.7 \\
79.4 \\
75.5 \\
80.1 \\
74.0 \\
68.9 \\
58.4 \\
79.3 \\
64.8 \\
76.2 \\
51.3 \\
78.1\end{array}$ & $\begin{array}{l}69.3 \\
74.4 \\
58.5 \\
77.3 \\
78.8 \\
83.9 \\
78.2 \\
69.4 \\
64.8 \\
80.6 \\
68.0 \\
74.1 \\
59.2 \\
80.6\end{array}$ \\
\hline $\begin{array}{c}154-928 \mathrm{~A}- \\
16 \mathrm{H}-2,47 \\
16 \mathrm{H}-3,73 \\
17 \mathrm{H}-3,81 \\
19 \mathrm{H}-3,85 \\
20 \mathrm{H}-3,81 \\
21 \mathrm{H}-2,110 \\
22 \mathrm{H}-3,34 \\
23 \mathrm{X}-3,75\end{array}$ & $\begin{array}{r}26.0 \\
48.6 \\
39.1 \\
81.8 \\
73.3 \\
0.7 \\
16.0 \\
48.2\end{array}$ & $\begin{array}{r}26.1 \\
49.8 \\
38.6 \\
84.5 \\
75.9 \\
0.5 \\
16.8 \\
51.9\end{array}$ & $\begin{array}{r}25.5 \\
50.4 \\
40.1 \\
79.7 \\
74.9 \\
3.1 \\
21.2 \\
42.4\end{array}$ & $\begin{array}{r}16.8 \\
50.6 \\
26.8 \\
75.7 \\
70.6 \\
9.4 \\
18.1 \\
79.8\end{array}$ \\
\hline $\begin{array}{l}154-929 \mathrm{~A}- \\
15 \mathrm{H}-1,77 \\
15 \mathrm{H}-3,79\end{array}$ & $\begin{array}{l}42.5 \\
26.5\end{array}$ & $\begin{array}{l}41.7 \\
24.4\end{array}$ & $\begin{array}{l}46.9 \\
28.1\end{array}$ & $\begin{array}{l}48.8 \\
35.9\end{array}$ \\
\hline
\end{tabular}

ter, et al., 1995) shows no systematic offsets (Fig. 2), with the differences within the analytical errors of the two techniques.

\section{RESULTS}

\section{Depth Transect of Carbonate Concentrations (5-10 Ma)}

Multisensor track measurements provide a rapid analysis of centimeter-scale changes in sediment properties and chemistry. The resulting records allow an evaluation of both high-frequency and longterm changes in the sediment record that can be examined in the context of climate and oceanographic change (Hagelberg et al., 1995a, 1995b; Shackleton et al., 1995). During ODP Leg 154, a number of sediment properties measured with the multisensor track and handheld Spectrophotometer were compared to the calcium carbonate content of the sediments (Curry, Shackleton, Richter, et al., 1995). Because the Ceara Rise sediments are largely a mixture of calcium carbonate and terrigenous material, properties such as magnetic susceptibility, color reflectance, and natural gamma radiation are highly correlated to the carbonate content. However, the shipboard studies showed that their relationships to carbonate content were not constant and changed from site to site and among the lithologic units. In this study we compared color reflectance (percentage at $550 \mathrm{~nm}$ ) and magnetic susceptibility data to measured $\% \mathrm{CaCO}_{3}$ values in samples from Site 925, 928, and 929 spanning the 5- to 10-Ma time interval (Fig. 3; Tables 2-4, see CD-ROM, back pocket, this volume).

Magnetic susceptibility and reflectance values for the sample depths were obtained by linear interpolation from shipboard measured depths. Magnetic susceptibility provides the best correlation $(\mathrm{r}=-0.95)$ to carbonate and one regression equation based on this relationship can be applied to all sites $\left(\% \mathrm{CaCO}_{3}=93.624-[2.164 \times\right.$ magnetic susceptibility]). Reflectance exhibits a curvilinear relationship with calcium carbonate and separate equations are needed for each site. This intersite difference is evident in Figure 3A where Site 928 values are shown

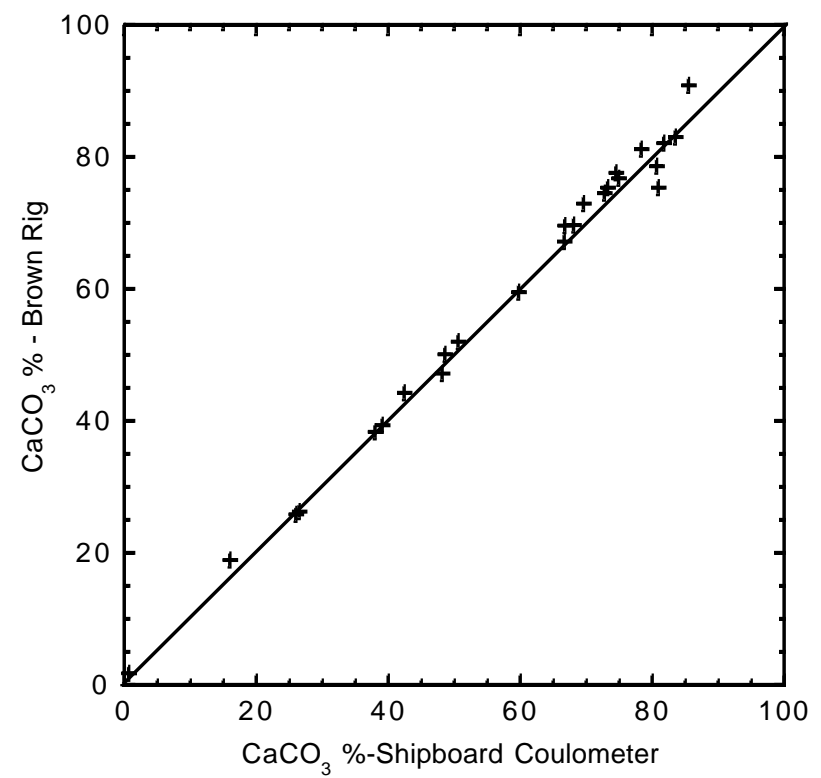

Figure 2. Scatter plot of calcium carbonate concentrations for 25 samples using the shipboard Coulometer (Curry, Shackleton, Richter, et al., 1995) and the automated rig at Brown University. The 1:1 correspondence line is shown (solid line).

to have higher reflectance values for the same calcium carbonate concentration than either Sites 925 or 929 . The accuracy of the magnetic susceptibility-based estimate is shown in Figure 4A. The estimated $\mathrm{CaCO}_{3}$ concentrations accurately represent the primary cycles in measured concentration with no major systematic offsets. Differences in the amplitude and structure of some cycles are evident (Fig. 4) and most likely result from variations in the composition of the non-carbonate portion of the sediments.

Carbonate concentrations estimated from magnetic susceptibility data measured on the shipboard composite of Sites 925, 928, and 929 for the intervals spanning approximately 5-10 Ma are shown in Figure 5. As noted previously, sections of Site 929 prior to $5.5 \mathrm{Ma}$ had either trace amounts of carbonate or were riddled with redeposited material. We do not include carbonate estimates from this older interval of Site 929 and assume that the site was at or below the CCD throughout this time period. Carbonate concentrations in Site 925 remained relatively high $(\bar{x}=77.2 \%)$ between 5 and 10 Ma (Fig. 5), whereas the concentrations in Site 928 ( $1000 \mathrm{~m}$ deeper) were more variable. We infer that these changes at the deep site reflect variable dissolution of $\mathrm{CaCO}_{3}$. Alternatively, the lower carbonate at depth could also reflect the input of terrigenous material from the prograding Amazon Fan. However, preliminary shipboard estimates of mean non-carbonate accumulation rates over this interval and the poor preservation of $\mathrm{CaCO}_{3}$ in the deeper Sites 928 and 929 suggest that carbonate dissolution was responsible for the large-scale changes. The late Miocene Site 925 carbonate record (Fig. 5) exhibits a highfrequency change in carbonate content that exhibits a precessional (23 k.y.) cyclicity (i.e., $\sim 5$ cycles/100 k.y.). These cycles do not appear to be well developed at the deeper sites. To determine the origin of these cycles and quantify the depth gradients of carbonate dissolution, we selected four intervals to examine in greater detail.

\section{Time Slices}

A total of 410 samples from Site 925, 154 samples from Site 928, and 60 samples from Site 929, covering the four time slices between 5 and $10 \mathrm{Ma}$, were analyzed for percentage coarse fraction and calci- 
A
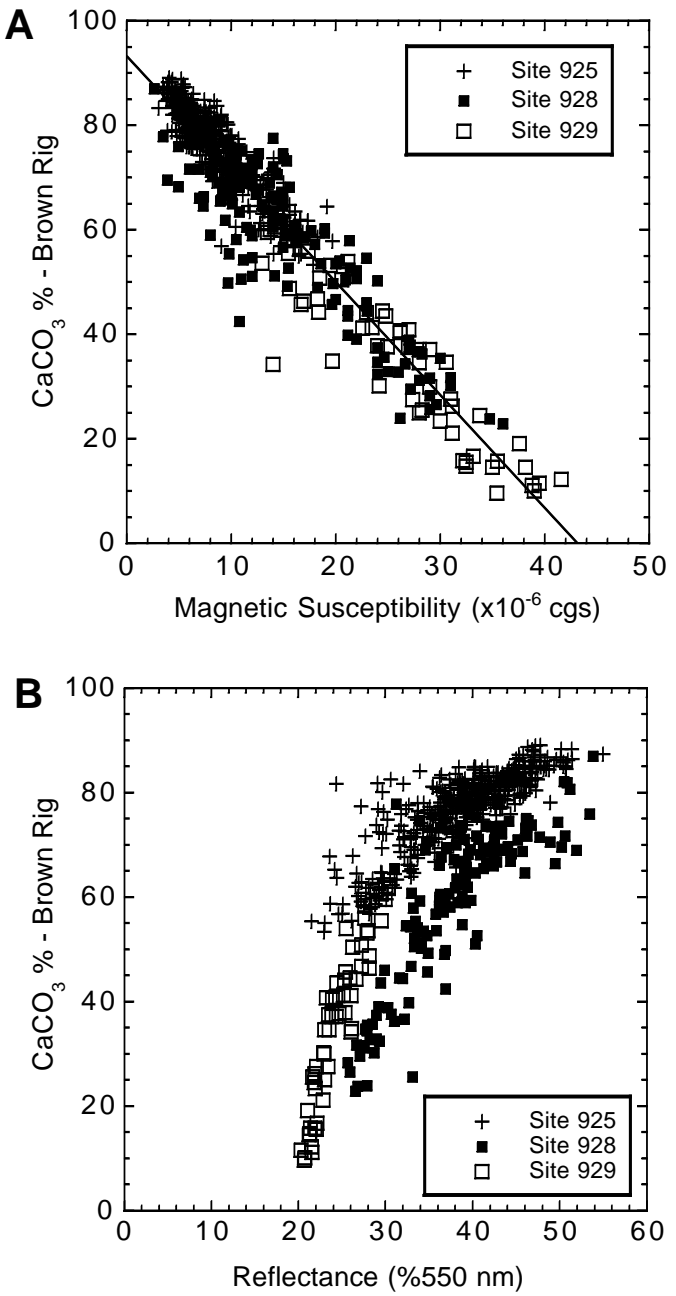

Figure 3. Scatter plots of (A) $\% \mathrm{CaCO}_{3}$ and magnetic susceptibility and (B) $\% \mathrm{CaCO}_{3}$ and reflectance for the 550-nm band for samples from Sites 925, 928, and 929. The linear regression model $\left(\% \mathrm{CaCO}_{3}=93.624-[2.164 \times\right.$ magnetic susceptibility]; $\mathrm{r}^{2}=0.90$ ) shown in (A) (solid line) was used to calculate calcium carbonate concentrations from the magnetic susceptibility measurements of the composite section between 5 and $10 \mathrm{Ma}$ at the three sites.

um carbonate concentration. Foraminiferal preservation data were obtained for 481 of these samples. These data are given in Tables 24 (see CD-ROM, back pocket, this volume). Chronologies for Sites 925, 928, and 929 were developed by King et al. (this volume). These age models are based on correlation of the carbonate changes at each site to the orbitally tuned record of carbonate cycles at Site 926 (Shackleton and Crowhurst, this volume). Ages were assigned to samples in this study through interpolation by assuming a linear sedimentation rate of composite depth between datums. Sedimentation rates were assigned to each sample by the composite depth and age difference between a sample and the adjacent older sample:

$$
\text { Sedimentation } \operatorname{rate}_{(\mathrm{i})}=\left[\operatorname{Depth}_{(\mathrm{i}+1)}-\operatorname{Depth}_{(\mathrm{i})}\right] /\left[\mathrm{Age}_{(\mathrm{i}+1)}-\mathrm{Age}_{(\mathrm{i})}\right] \text {. }
$$

Dry densities, needed to calculate mass accumulation rates (MARs), were estimated from shipboard gamma-ray attenuation porosity evaluator (GRAPE) measurements. Separate relationships were developed for each site based on the comparison of discrete dry density (Curry, Shackleton, Richter, et al.. 1995) and GRAPE measurements over the interval of study (Table 5). GRAPE values were assigned to sample depth in this study by linear interpolation. We applied the equations given in Table 5 to calculate the dry-density values given in Tables 2-4. The composites of GRAPE data from all three sites showed a number of sections with anomalous low values that we consider spurious and unreliable. Data from these sections were deleted from the composite, and densities are assumed to change linearly through these intervals (see notes in Tables 2-4). Because of the small density changes observed, this assumption should not introduce significant errors to the MARs.

As noted by the shipboard studies (Shipboard Scientific Party, $1995 \mathrm{~b}$ ), there is a general correlation of carbonate concentration and density at the Ceara Rise sites, with higher densities observed in the carbonate-poor sections. This relationship is atypical for pelagic marine settings containing mostly carbonate and terrigenous material (Herbert and Mayer, 1991) and may result from differential compaction of a lithogenic component that is enriched in quartz (see Herbert et al., this volume). Of the three sites studied, the carbonate and density relationship was best developed at the shallow Site 925 (Figs. 6, 7). In addition, Figure 7 shows that the densities in time slice 1 are significantly less than those in deeper Site 925 samples with similar carbonate contents. This reflects the normal downhole increase in density attributed to compaction. Shipboard scientists observed that the depth interval from 210 to $340 \mathrm{mbsf}$, which includes time slices 3 and 4 had an inverse or only a small density change with depth (Shipboard Scientific Party, 1995b). This may explain the lack of the normal downhole increase in density among time slices 2 through 4 (Fig. 7). Detailed investigation of the cause of this lack of gradient in the densities was beyond the scope of this study.

\section{Time Slice 1 (5.0-5.4 Ma)}

Calcium carbonate concentrations at Site 925 between 4.9 and 5.5 Ma have a low amplitude of variability, ranging from $60 \%$ to $89 \%$ with a cyclic period of close to $23 \mathrm{k} . \mathrm{y}$. (Fig. 8). The largest variations occur between 5.0 and $5.18 \mathrm{Ma}$, with a significant low in carbonate concentration near $5.06 \mathrm{Ma}$. This decrease is accompanied by a decrease in foraminifer preservation (Forams \% in Fig. 8). Foraminifers are very well preserved throughout much of this time interval and, with the exception of the event near 5.06 Ma, these data indicate that dissolution plays a small role in variations in carbonate content at this site. Variations in coarse fraction $(\%>63 \mu \mathrm{m})$, commonly used as a dissolution index (Berger et al., 1982; Peterson and Prell, 1985), bear little resemblance to the foraminifer index of dissolution from Site 925. Since all the $>63 \mu \mathrm{m}$ fraction consists of biogenic carbonate material, weight changes in the fine fraction may potentially be attributed to terrigenous dilution. In an attempt to ameliorate the dilution problem, we scaled the coarse fraction as a function of calcium carbonate concentration (Shackleton and Crowhurst, this volume) [wt $\%$ $>63 \mu \mathrm{m}$-scaled $\left.=100 \times\left(\mathrm{wt} \%>63 \mu \mathrm{m} / \% \mathrm{CaCO}_{3}\right)\right]$, to show weight changes in the carbonate portion of the sediments. Note that the decrease in foraminifer preservation and $\% \mathrm{CaCO}_{3}$ near $5.06 \mathrm{Ma}$ is not associated with a decrease in the scaled coarse fraction, but it is associated with a decrease in weight percentage $>63 \mu \mathrm{m}$ (Fig. 8). We infer from these data that terrigenous dilution is responsible for at least some of the $\% \mathrm{CaCO}_{3}$ decrease.

The accumulation rates of both carbonate and terrigenous components are variable between 5.0 and $5.4 \mathrm{Ma}$ (Fig. 8), suggesting that changes in both production and dilution are likely factors. Note that the interval from 5.04 to 5.15 Ma has both high-scaled coarse fraction and low carbonate MARs. Taken together, these suggest that finefraction carbonate decreased, either as a result of changes in production or winnowing. Further work, which includes assessing carbonate 
Age (Ma)
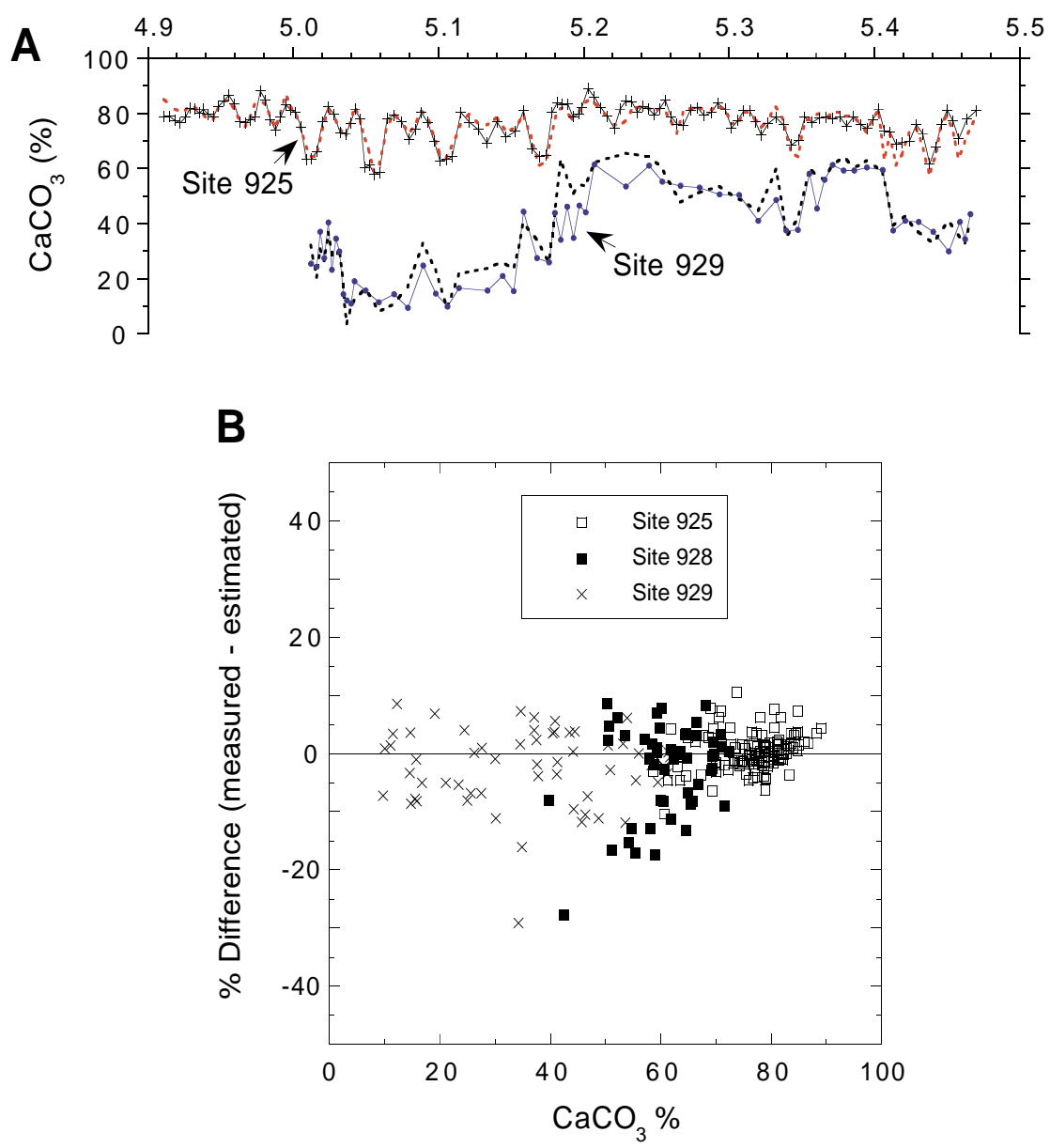

Figure 4. A. Calcium carbonate vs. age for Site 925 (solid with pluses) and Site 929 (solid with dots) for time slice 1. The dashed line associated with each carbonate time series is the calcium carbonate concentration estimated from magnetic susceptibility. Ages are based on the orbitally tuned age models given in King et al. (this volume). B. Percent difference of measured and estimated carbonate vs. $\% \mathrm{CaCO}_{3}$ in the first time slice for Sites 925,928 , and 929.

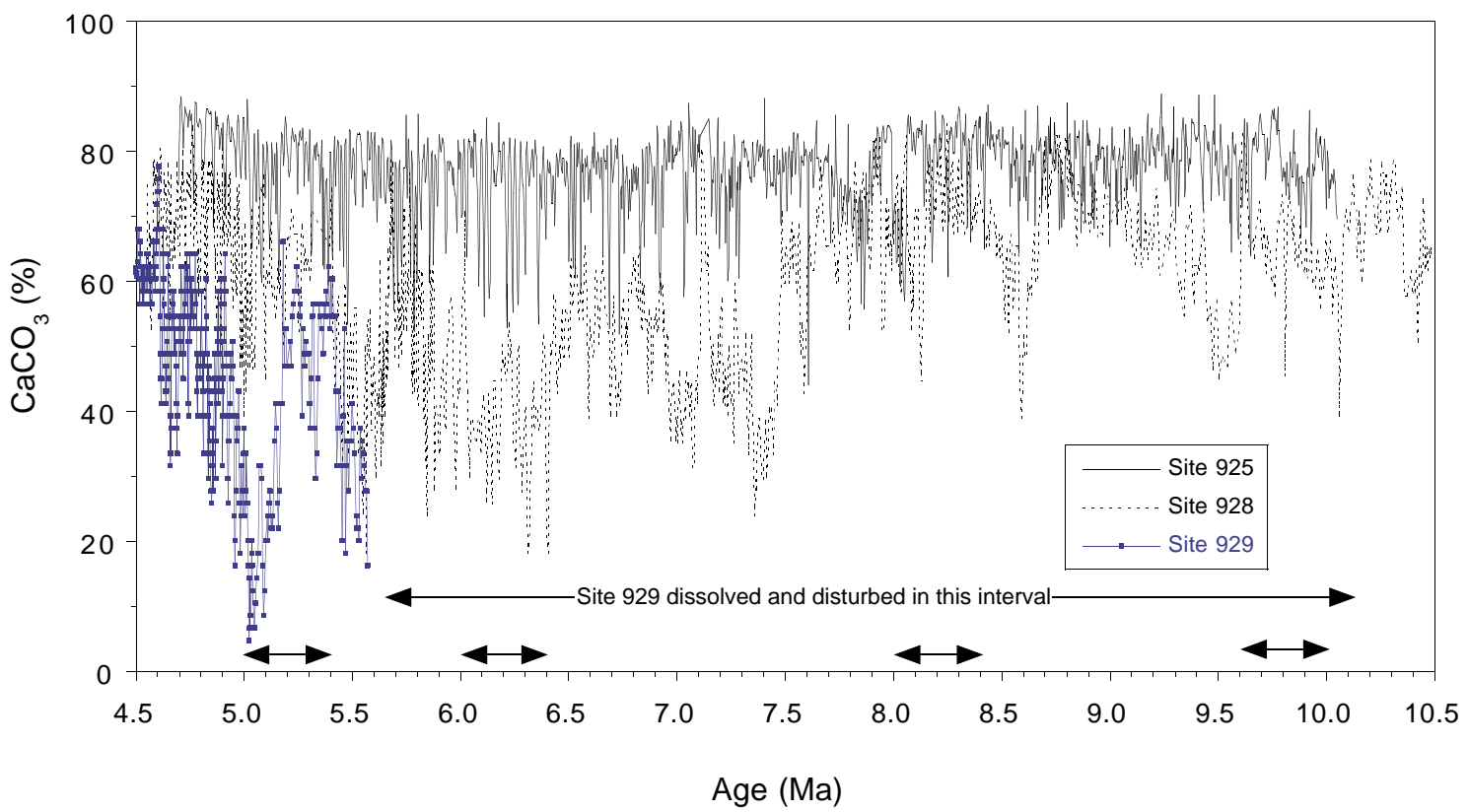

Figure 5. Time series of magnetic susceptibility-based estimates of calcium carbonate for the composite section from Sites 925,928 , and 929 between $~ 5$ and 10 Ma. The shipboard age model based on biostratigraphic datums (Curry, Shackleton, Richter, et al., 1995) was used to assign ages to the composite sections at each site. The arrows denote the four time slices sampled at high resolution for this study. The Site 929 sedimentary section in the 5.5-10.0 time interval had either trace amounts of carbonate or redeposited material and the site is considered to be at or below the carbonate compensation depth throughout this period. 
Figure 6. Time series showing the covariation of $\mathrm{CaCO}_{3}$ (solid line with pluses) and dry density (solid line with squares) for the first time slice from Site 925 . Note that the dry density values are inverted. Ages are based on the orbitally tuned age model from King et al. (this volume).

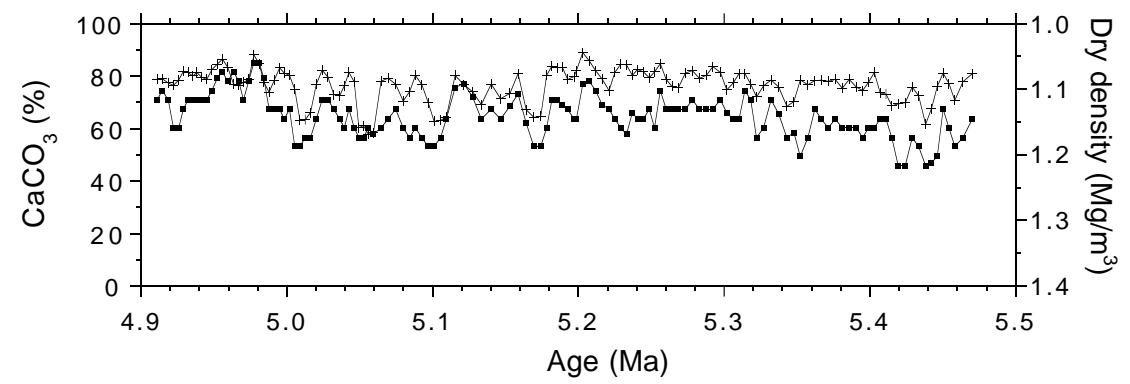

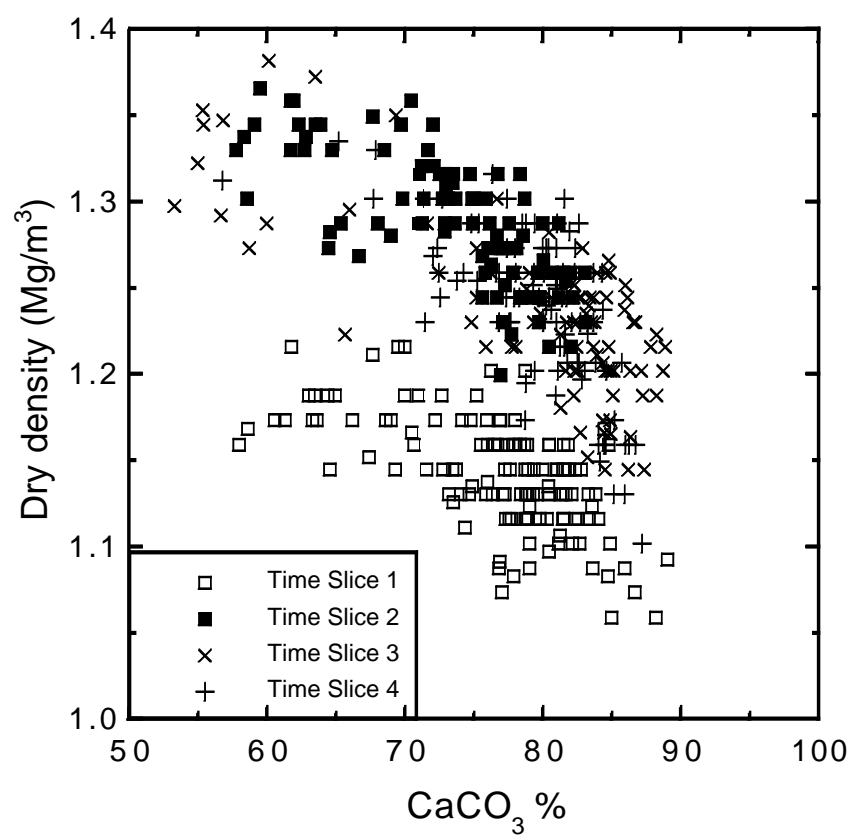

Figure 7. Scatter plot of dry density and $\% \mathrm{CaCO}_{3}$ for Site 925 samples used in this study.

productivity indices, is necessary to differentiate between these two factors. We are presently generating stable isotope data for all the Site 925 samples, which will be used to provide an independent check of the chronostratigraphy for future studies.

As compared with Site 925, the 5.1- to 5.4-Ma time interval at Site 928 has significantly lower carbonate concentrations and greatly increased dissolution of the carbonate fraction, as indicated by decreased foraminifer preservation (Fig. 9). Unlike Site 925, where the coarse fraction changes bear little resemblance to the record of carbonate concentration or foraminifer dissolution, the coarse fraction (>63 $\mu \mathrm{m}$ ) at Site 928 appears to be a good record of the preservation. The carbonate cycles at Site 928 have a strong dissolution overprint, and this overprint made it difficult to match cycles at the deeper site to the orbitally tuned, but minimally dissolved cycles at Sites 925 and 926 (King et al., this volume). Other difficulties arose because the deeper sites contained disturbed sections, either related to coring (flow-in noted at 5.38-5.4 Ma in Site 928, Fig. 9) or downslope movement of sediments associated with slumps or turbidites (5.185.2 Ma in Site 928, Fig. 9). The high sedimentation and accumulation rates for these disturbed intervals result in inversions of the water depth gradient of carbonate accumulation (Fig. 10). Clearly, more work is needed to place better age controls and identify disturbed sections at the deeper sites than could be achieved in this preliminary study. However, the mean accumulation rates are nevertheless useful in quantifying the carbonate loss with depth. If the disturbed deposits are included in the 5- to 5.4-Ma interval, these reflect minimum loss- es. For the common intervals of Site 925 and 928 , there is an average loss of $20 \%\left(3.5 \mathrm{~g} / \mathrm{m}^{2} / \mathrm{yr}\right)$ per $1000 \mathrm{~m}$ of water depth. Note that this loss is not as apparent in the concentration data (Fig. 10), a point made by a number of other studies (e.g., Broecker and Peng, 1982).

Site 929, about $330 \mathrm{~m}$ deeper than Site 928, has even more dissolution of carbonate (Fig. 10). From before 5.5 Ma until at least $10 \mathrm{Ma}$, little carbonate accumulated at Site 929 as a primary deposit. Between 5.0 and $5.1 \mathrm{Ma}$, most of the $20 \mathrm{~g} / \mathrm{m}^{2} / \mathrm{yr}$ carbonate flux reaching the shallow Site 925 is dissolved at the water depth of Site 929. The interval from Site 929 between 5.15 and 5.5 Ma is relatively enriched in carbonate. Examination of the photos and barrel sheets for Core 154-929A-15H (Curry, Shackleton, Richter, et al., 1995) reveals that much of the material is redeposited and the apparent increase in preservation is an artifact produced by downslope transport of material. In Site 929 sediments younger than 5.0 Ma, preservation increases, and the site remains above the CCD to the present (Shipboard Scientific Party, 1995c).

\section{Time Slice $2(6.0-6.4 \mathrm{Ma})$}

Sampling of the time slices for this study was done using shipboard biostratigraphic ages, and time slice 2 was selected to span the 6.0- to 6.4-Ma time interval. For Site 925, the revised chronostratigraphy based on orbital tuning did not make significant age changes to our samples (Fig. 11). However, significant age offsets are evident at Site 928 with the new chronostratigraphy, which resulted in sampled sections in Site 928 without temporal overlap with Site 925 samples for either the 6- to 6.4-Ma and 8- to 8.4-Ma time periods. Although comparison of the dissolution indices is impossible, magnetic susceptibility-based estimates of calcium carbonate concentrations can be used in conjunction with density and sedimentation rate data to construct time series of calcium carbonate concentration and accumulation as well as non-carbonate accumulation (Figs. 11, 12). In both time intervals, overlapping sections of measured and estimated $\% \mathrm{CaCO}_{3}$ yield essentially the same results. The depth gradient of $\% \mathrm{CaCO}_{3}$ in the 6.1- to 6.7-Ma time interval exhibits substantial variation. The amplitude of the cycles in carbonate and foraminiferal preservation at Site 925 are similar to those observed between 5.04 and 5.15 Ma (Fig. 10). At Site 928, the carbonate changes are more variable in amplitude, but the cycles are more defined compared to the 5.0- to 5.4-Ma time interval. Preservation between 6.4 and $6.7 \mathrm{Ma}$ at Site 928 is the lowest of all the intervals studied, with the low mean $\mathrm{CaCO}_{3}$ concentration $(36.5 \%)$ and MAR $\left(6.5 \mathrm{~g} / \mathrm{m}^{2} / \mathrm{yr}\right)$, as well as low whole foraminifer percentages and weight percentages $>63 \mu \mathrm{m}$, reflecting the increased effects of dissolution. We infer that the CCD was close to the depth of Site 928 during this time interval.

\section{Time Slice $3(8.0-8.4 \mathrm{Ma})$}

Both Sites 925 and 928 contain disturbed sections in the respective time periods sampled as part of this interval (Fig. 12). The carbonate decrease observed in Site 925 between 8.01 and $8.06 \mathrm{Ma}$ and the substantial increase in MAR near 8.28, 8.42, and 8.74 Ma are disturbances associated with mass wasting. Most of the Site 928 section prior to $8.6 \mathrm{Ma}$ is thought to be a slump. Because of these disturbanc- 


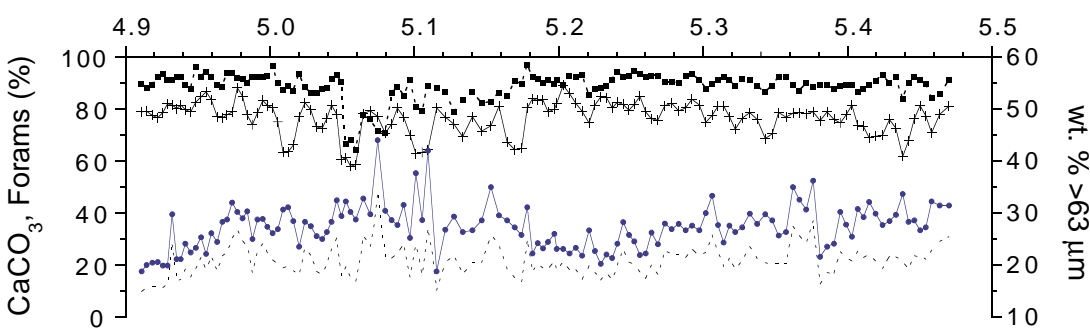

Site 925
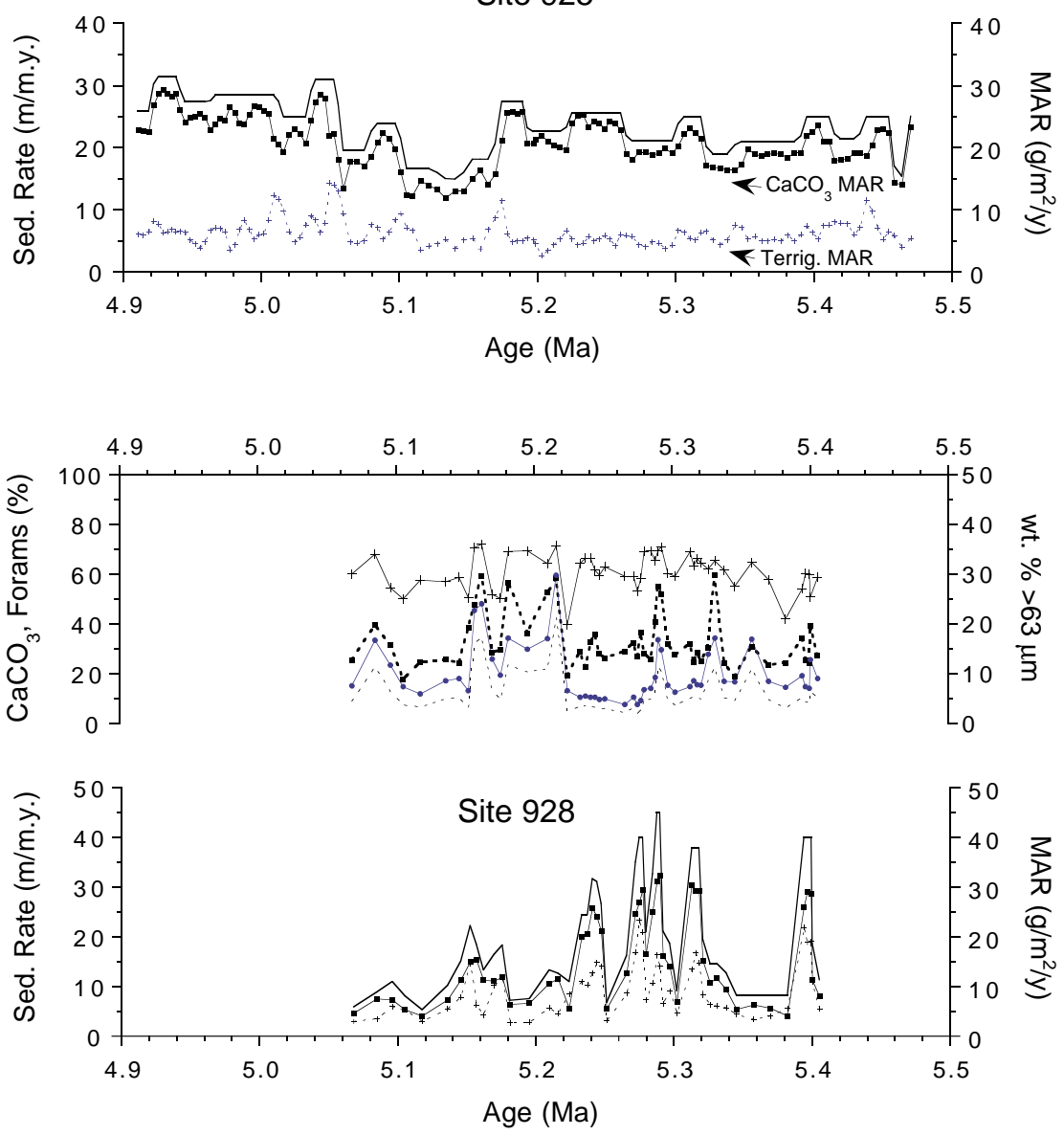

Figure 8. Time series of $\% \mathrm{CaCO}_{3}$ (solid line with pluses), percentage whole foraminifers (dashed line with squares), weight percent $>63 \mu \mathrm{m}$ (dashed line), weight percent $>63$ $\mu \mathrm{m}$ scaled (solid line with dots), sedimentation rate (solid line), $\mathrm{CaCO}_{3}$ MAR (solid line with squares), and terrigenous MAR (dashed line with pluses) for Site 925 from the first time slice. The age model is from King et al. (this volume $)$. The scaled $\mathrm{wt} \%>63 \mu \mathrm{m}=[100 \times(\mathrm{wt} \%>63 \mu \mathrm{m}$ $\left.1 \% \mathrm{CaCO}_{3}\right)$ ]. Terrigenous percentage used in the Terrigenous MAR calculation is estimated as $100-\% \mathrm{CaCO}_{3}$.

Figure 9. Time series of $\% \mathrm{CaCO}_{3}$ (solid line with pluses), percentage whole foraminifers (dashed line with squares), weight percent $>63 \mu \mathrm{m}$ (dashed line), weight percent $>63-\mu \mathrm{m}$ scaled (solid line with dots), sedimentation rate (solid line), $\mathrm{CaCO}_{3}$ MAR (solid line with squares), and terrigenous MAR (dashed line with pluses) for Site 928 from the first time slice. The age model is from King et al. (this volume).

es, orbital tuning of the carbonate cycles in these sections is likely to produce anomalous ages.

The section between 8.06 and 8.26 Ma in Site 925 appears undisturbed and contains the characteristic high $\mathrm{CaCO}_{3}$ concentrations and MARs, as well as well-preserved foraminifers that are observed in the middle to late Miocene at this site. Although the mean rates of accumulation seem higher for the section sampled at Site 928, much of the increase is within the slumped deposit. Considering only the undisturbed intervals, the low rates and poor preservation are consistent with placement of the CCD near the depth of Site 928, but deeper than in the 6.4- to 6.7-Ma time interval.

\section{Time Slice $4(9.6-10.0 \mathrm{Ma})$}

Although much of the section sampled in Site 925 between 9.9 and 10.2 Ma appears undisturbed, most of the Site 928 samples are from disturbed sections and are thought to be redeposited slump or turbidite material. This may account for the relatively high carbonate contents observed in Site 928 (Fig. 13), which produce an anomalously low depth gradient. The foraminifer preservation and carbon- ate concentrations for Site 925 indicate very little dissolution of the calcium carbonate portion of the sediments at this site. Between 9.9 and 10.0 Ma, there is a substantial decrease in the accumulation of carbonate MAR. This decrease, if real, can most likely be attributed to a decrease in the fine-fraction production or winnowing, because it is not accompanied by a decrease in preservation and the coarse fraction is relatively high.

\section{DISCUSSION}

Curry and Lohmann (1990) quantified carbonate accumulation on the Ceara Rise for the Holocene and last glacial maximum. Accumulation rates at the sites above $3500 \mathrm{~m}$ for the last $18,000 \mathrm{yr}$ were close to $10 \mathrm{~g} / \mathrm{m}^{2} / \mathrm{yr}$. Because the sediments above $3500 \mathrm{~m}$ are well preserved, these accumulation rates provide a reasonable approximation of the carbonate production rate in the euphotic zone (Curry and Lohmann, 1990). Similar carbonate accumulation rates are observed at other equatorial sites on the western side of ocean basins. Using data from Kroenke, Berger, Janecek, et al. (1991) for Site 807 (2804 m 

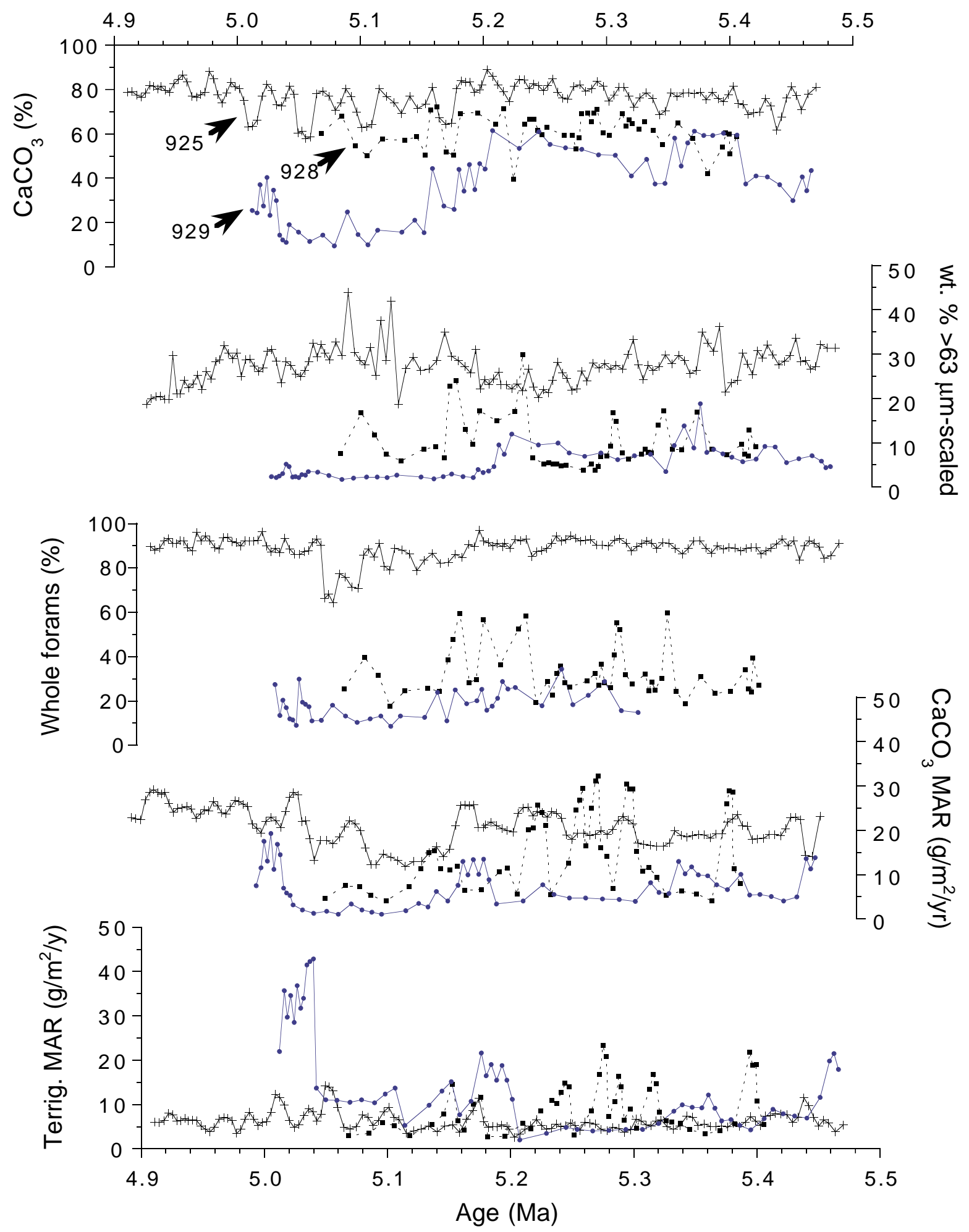

Figure 10. Time series showing the depth transect of $\% \mathrm{CaCO}_{3}$, percentage whole foraminifers, weight percent $>63-\mu \mathrm{m}$ scaled, $\mathrm{CaCO}_{3} \mathrm{MAR}$, and terrigenous MAR for the depth transect of Sites 925 (solid line with pluses), 928 (dashed line with squares), and 929 (solid line with dots) for the first time slice. Ages are based on the orbitally tuned age models from King et al. (this volume). Spikes in the MARs for Site 928 between 5.2 and 5.4 Ma are attributed to poor chronostratigraphic control in sections of disturbed or redeposited material. 

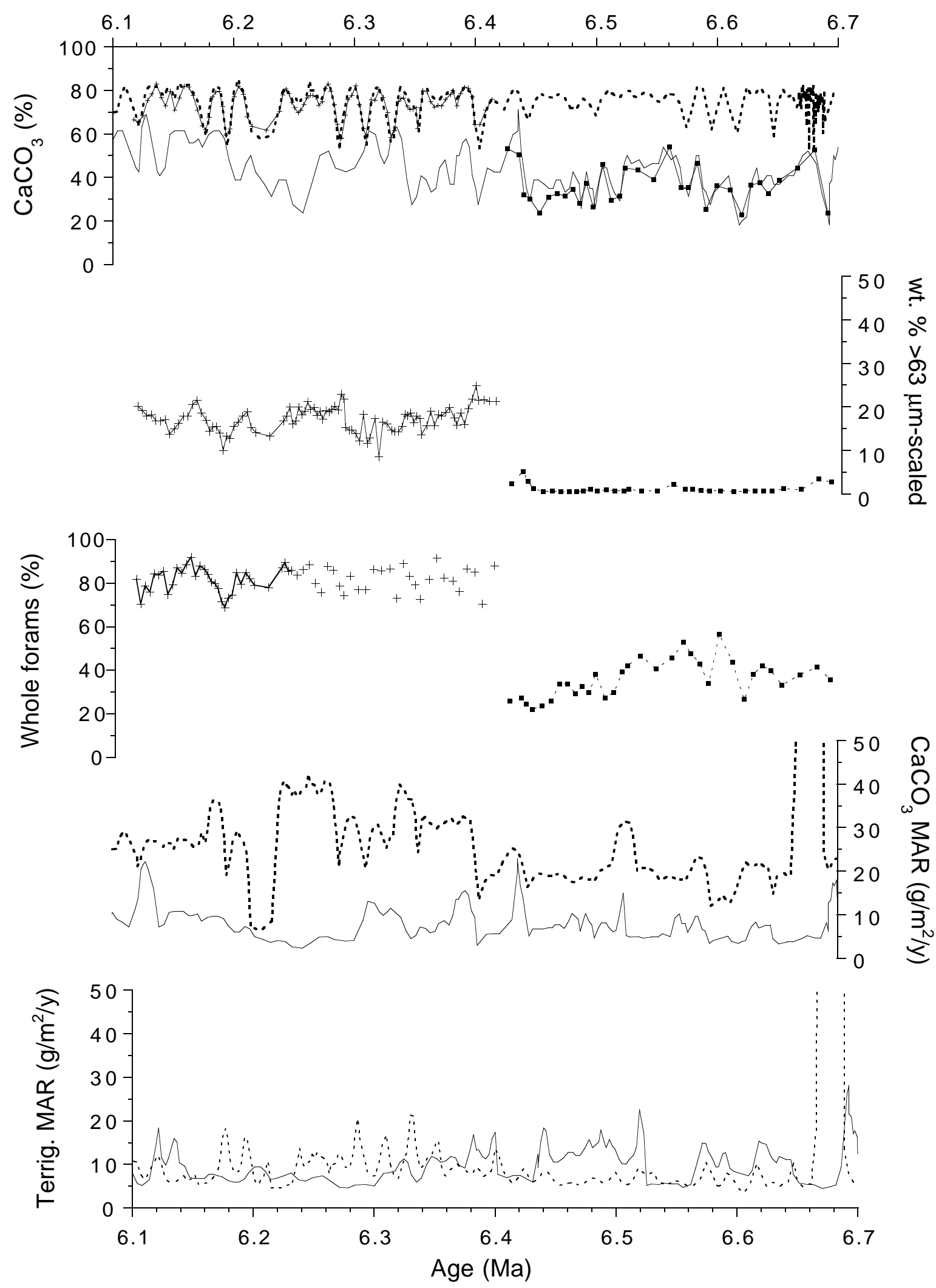

Figure 11. Time series showing the depth transect of $\% \mathrm{CaCO}_{3}$, percentage whole foraminifers, weight percent $>63-\mu \mathrm{m}$ scaled, $\mathrm{CaCO} \mathrm{MAR}_{3}$, and terrigenous MAR for Sites 925 and 928 in time slice 2. Because sampled sections are offset in age, the $\% \mathrm{CaCO}_{3}$ was estimated from magnetic susceptibility. The resulting estimated concentration and MAR data are shown as dashed (Site 925) and solid (Site 928) lines. The Site 925 percentage whole foraminifer samples analyzed at a 20-cm spacing are not connected by lines. For depth transect of $\% \mathrm{CaCO}_{3}$, percentage whole foraminifers, and weight percent $>63-\mu \mathrm{m}$ scaled, Site $925=$ solid line with pluses, Site $928=$ dashed line with squares, and Site $929=$ solid line with squares. 

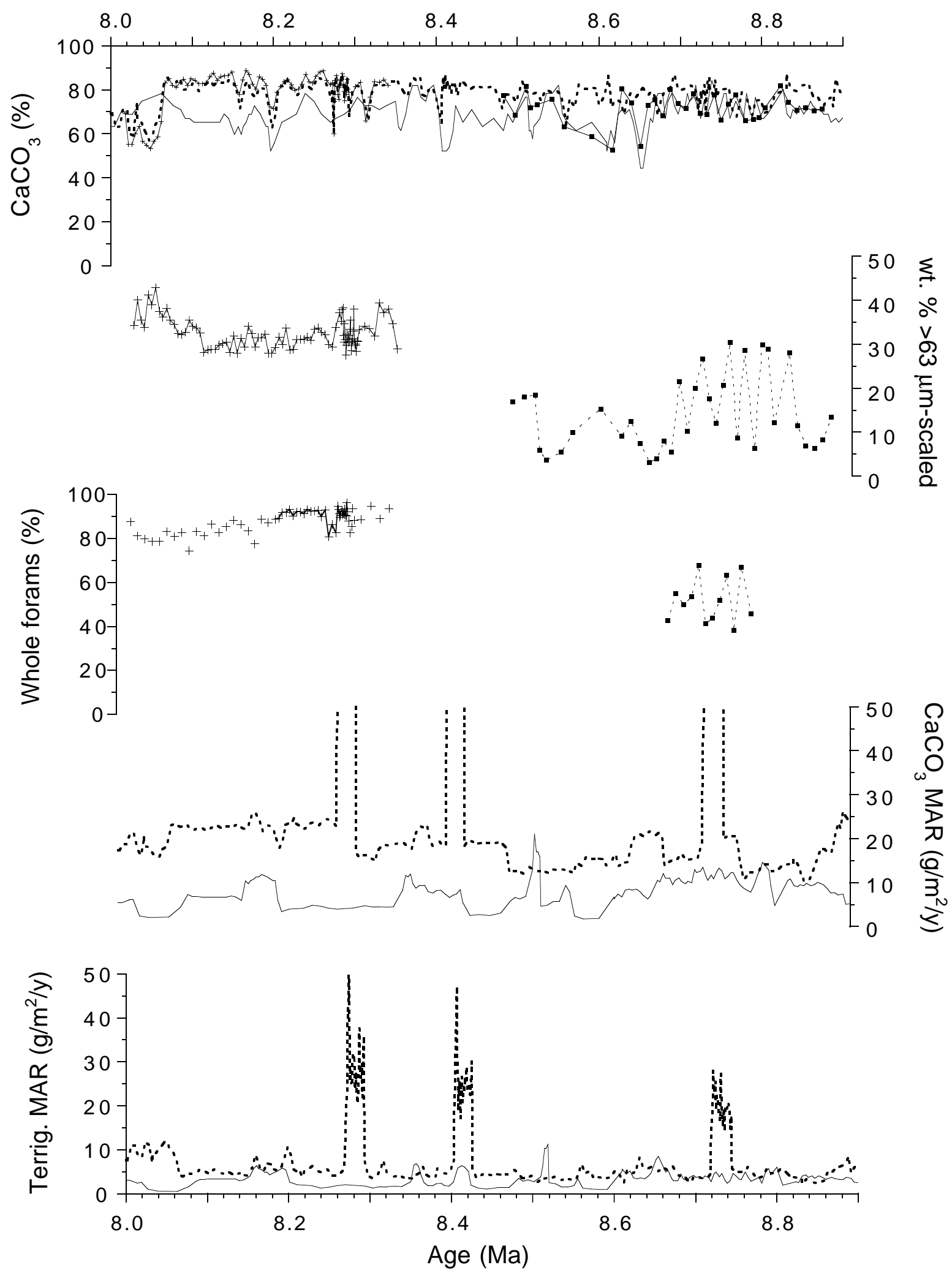

Figure 12. Time series showing the depth transect of $\% \mathrm{CaCO}_{3}$, percentage whole foraminifers, weight percent $>63-\mu \mathrm{m}$ scaled, $\mathrm{CaCO} \mathrm{MAR}_{3}$, and terrigenous MAR for Sites 925 and 928 in time slice 3. Because sampled sections are offset in age, the $\% \mathrm{CaCO}_{3}$ was estimated from magnetic susceptibility. The resulting estimated concentration and MAR data are shown as dashed (Site 925) and solid (Site 928) lines. The spikes in MAR for Site 925 are in intervals containing redeposited material. 

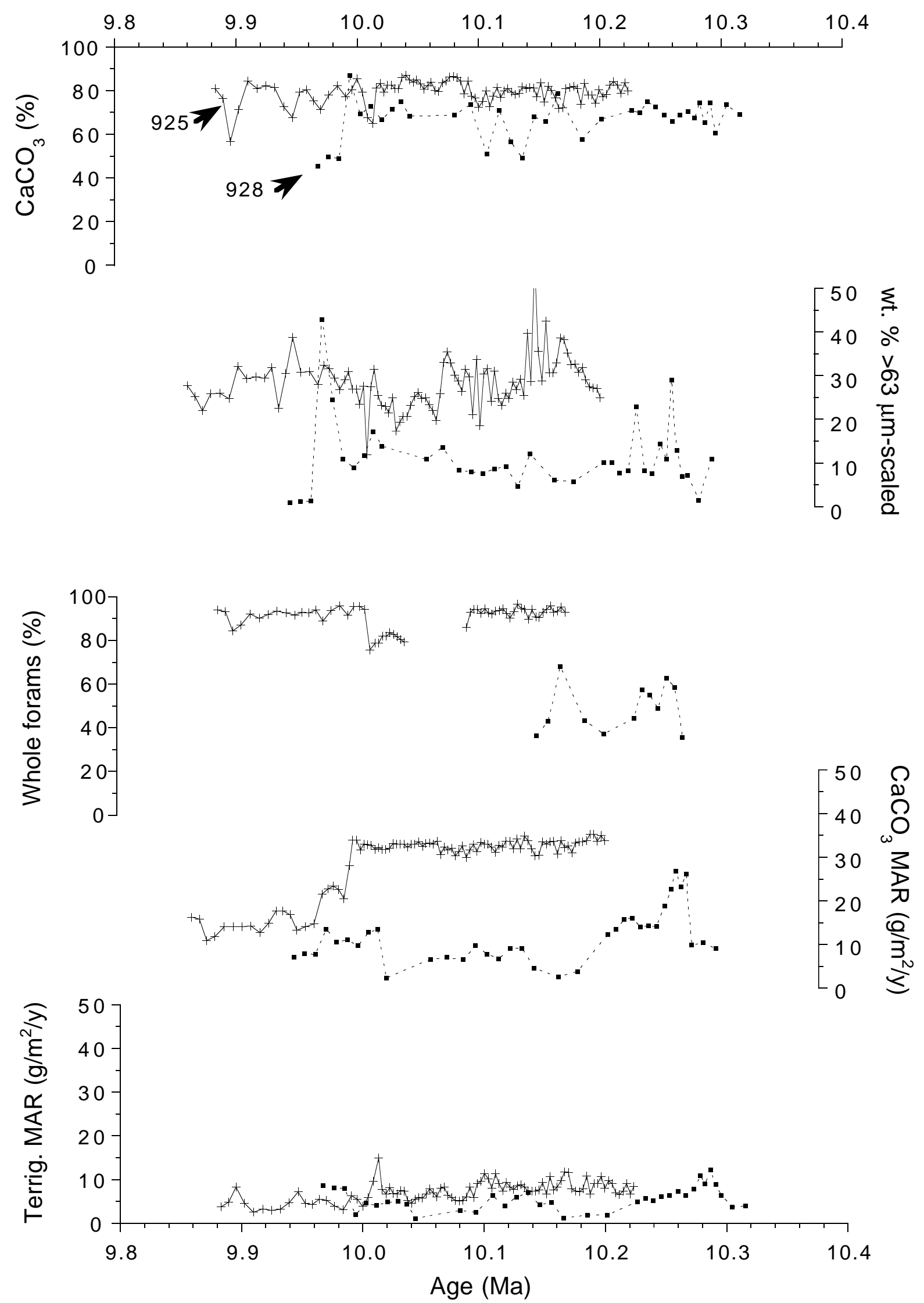

Figure 13. Time series showing the depth transect of $\% \mathrm{CaCO}_{3}$, percentage whole foraminifers, weight percent $>63-\mu \mathrm{m}$ scaled, $\mathrm{CaCO} \mathrm{MAR}_{3}$, and terrigenous MAR for the depth transect of Sites 925 and 928 for time slice 4. 
A $\mathrm{CaCO}_{3} \mathrm{MAR}\left(\mathrm{g} / \mathrm{m}^{2} / \mathrm{y}\right)$

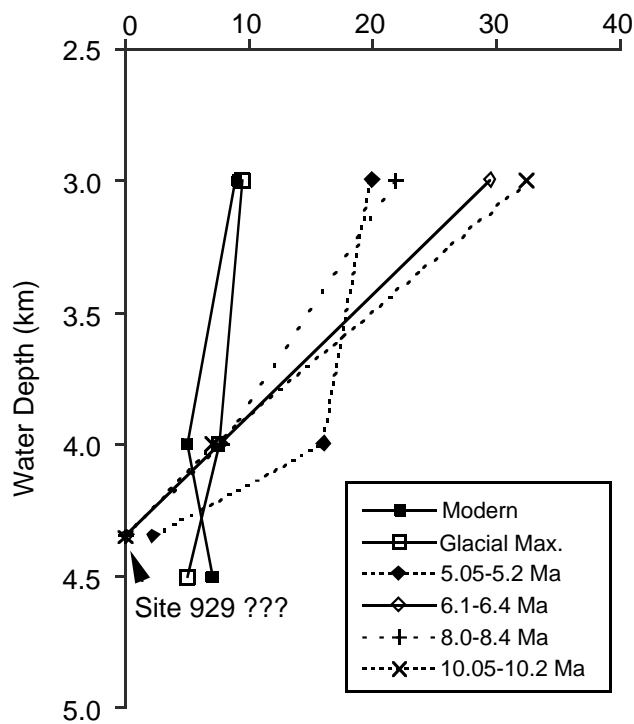

B $\mathrm{CaCO}_{3} \operatorname{MAR}\left(\mathrm{g} / \mathrm{m}^{2} / \mathrm{y}\right)$

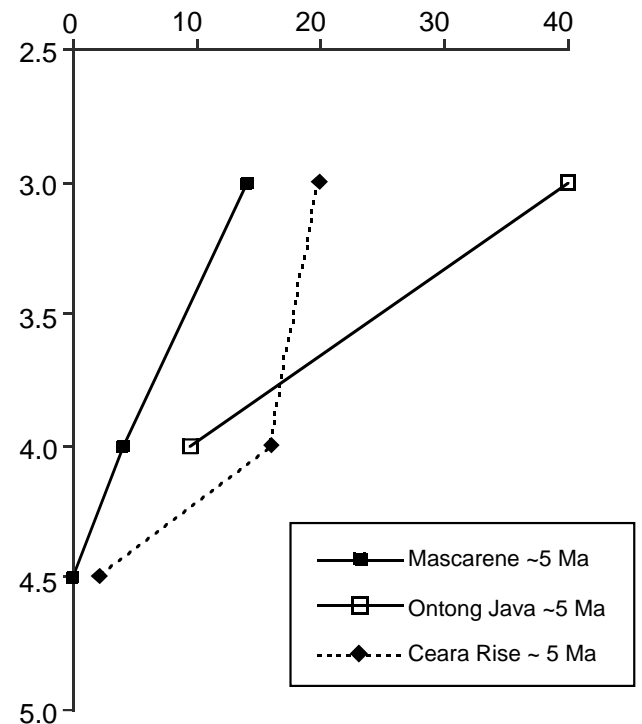

Figure 14. A. Depth transects of carbonate accumulation on the Ceara Rise for time intervals indicated. The intervals were chosen to avoid sections of redeposited material. B. Depth transects of carbonate accumulation that have increased carbonate sedimentation at the shallow sites compared to the modern rates for the Mascarene Plateau (Sites 709, 710, 711), the Ontong Java Plateau (Sites 807 and 804), and the Ceara Rise (Sites 925, 928, and 929) for the time interval near $5 \mathrm{Ma}$.

water depth) in the western equatorial Pacific, we calculate a calcium carbonate MAR of $10.8 \mathrm{~g} / \mathrm{m}^{2} / \mathrm{yr}$ for the most recent sediments cored at this site. Peterson and Backman (1990) show a rate near $9 \mathrm{~g} / \mathrm{m}^{2} / \mathrm{yr}$ for Site 709 (3038 m water depth) from the western equatorial Indian Ocean. For comparison, eastern equatorial sites in the Pacific with minimal dissolution have calcium carbonate accumulation rates near $12 \mathrm{~g} / \mathrm{m}^{2} / \mathrm{yr}$ (Lyle, 1992; Murray et al., 1995), which are not significantly higher than those in the western Pacific. However, this rate may be an underestimate of carbonate production because some postdepositional loss of carbonate due to organic matter degradation (e.g., Emerson and Bender, 1981; Peterson and Prell, 1985; Archer, 1991) is likely in eastern basin sites that receive a relatively large input of organic matter. More realistic estimates of the carbonate production come from sediment traps moored in the high productivity zone in the eastern equatorial Pacific (Honjo et al., 1995). The measured rates in the traps during non-El Niño conditions are above $20 \mathrm{~g} /$ $\mathrm{m}^{2} / \mathrm{yr}$, more than twice the accumulation at the shallow western basin sites.

At Ceara Rise, as well as the other western equatorial sites, a substantial loss of carbonate is observed at sites near $4000 \mathrm{~m}$, attributed to depth-dependent dissolution of carbonate. Curry and Lohmann (1990) showed a 50\% loss of carbonate in coretop sediments below $4000 \mathrm{~m}$ as compared with coretops retrieved above $4000 \mathrm{~m}$ on the Ceara Rise. This depth-dependent loss through dissolution is even more evident for sediments deposited during the last glacial maximum (Curry and Lohmann, 1990), an observation attributed to an increase in the proportion of the more corrosive AABW relative to NADW, as compared with the Holocene.

A comparison of modern fluxes to the carbonate accumulation rates from this study reveals temporal changes in production and depth-dependent dissolution (Fig. 14). The mean rate of carbonate deposition near $3000 \mathrm{~m}$ during the late Miocene was more than twice the modern rate (Fig. 14A). These high rates are typical of those measured today in sediment traps moored in the equatorial Pacific (Honjo et al., 1995). In contrast to the eastern equatorial Pacific sites where a high input of organic matter causes significant dissolution above the lysocline, the shallow deposits from the late Miocene on the
Ceara Rise exhibit minimal dissolution. We infer that the high production of carbonate was not associated with a relative increase in organic matter production, or if organic production increased, the sediments were buffered against dissolution driven by organic matter decay (see Archer, 1991, for a discussion of the organic matter influence on dissolution).

This late Miocene increase in "blue ocean" production (Brummer and van Eijden, 1992) is observed globally at shallow sites in the tropical ocean and in the north Pacific (Fig. 4B; Peterson et al., 1992; Berger et al., 1993; Leg 145 Shipboard Scientific Party, 1993; Farrell et al., 1995). As noted earlier, Berger et al. (1993) proposed that increased flow of NADW could be responsible for the simultaneous increase in both production and depth-dependent dissolution observed in western Pacific sites at this time. However, this process should result in a corresponding increase in carbonate deposition in the deep Atlantic to balance the deficit found in the deep Pacific. As shown by the results of this study (Fig. 14), the dissolution gradient at Ceara Rise during the late Miocene was dramatically higher than the Holocene $\left(15 \mathrm{~g} / \mathrm{m}^{2} / \mathrm{yr} / \mathrm{km}\right.$ vs. $\left.3 \mathrm{~g} / \mathrm{m}^{2} / \mathrm{yr} / \mathrm{km}\right)$, corresponding to a shoaling of the CCD. Peterson et al. (1992) note that shoaling of the CCD in this interval does occur at a time of rising sea level (i.e., Haq et al., 1987), and shallow to deep partitioning of carbonate is thus likely to be at least partly responsible for the change in gradient. In the absence of an increased supply rate of $\mathrm{Ca}^{+2}$, the combined effect of more shallow areas for deposition (sea level) and increased open ocean carbonate production should act to increase the carbonate dissolution gradient. To test the potential role of production change in NADW, studies of interbasinal $\delta^{13} \mathrm{C}$ gradients in deep water (e.g., Woodruff and Savin, 1989; Wright et al., 1992) are clearly needed.

The orbitally tuned age model reveals cyclic changes in carbonate and terrigenous accumulation. Because of the preliminary nature of the correlations between shallow and deep sites, we await higher resolution biostratigraphy and stable isotope data to discuss orbital-scale changes in the variations in carbonate production and depth-dependent dissolution.

Preliminary shipboard studies (Shipboard Scientific Party, 1995a) showed an increase in the terrigenous flux at Ceara Rise sites near 8 
Ma. Because the Ceara Rise sediments are largely a mixture of biogenic carbonate and terrigenous materials, the non-carbonate accumulation rates primarily reflect changes in terrigenous input to the Ceara Rise. The present source of these terrigenous sediments is the Amazon River outflow. The terrigenous MARs at Site 925 were significantly higher in time slice $2\left(6-6.4 \mathrm{Ma} ; 11.2 \mathrm{~g} / \mathrm{m}^{2} / \mathrm{yr}\right)$ compared to the older two intervals $\left(6 \mathrm{~g} / \mathrm{m}^{2} / \mathrm{yr}\right)$, which is consistent with the shipboard findings (Shipboard Scientific Party, 1995a). Although a significant decrease in terrigenous MAR occurred between time slices 1 and 2 (from 11.2 to $6.4 \mathrm{~g} / \mathrm{m}^{2} / \mathrm{yr}$ ), the shipboard studies show a dramatic increase in terrigenous flux since 5.0 Ma, to rates approaching $17 \mathrm{~g} / \mathrm{m}^{2} / \mathrm{yr}$ for the modern. Such a large increase may be related to increased erosion of the Andes caused by accelerated uplift (Benjamin et al., 1987) and/or global cooling. This topic is considered by other studies in this volume.

\section{SUMMARY AND FUTURE STUDY}

Our study of carbonate sedimentation between $\sim 5$ and $10 \mathrm{Ma}$ shows dramatic changes in both the production and depth-dependent dissolution of calcium carbonate in this time period as compared with the present. In this time interval, a simple relationship between reflectance and carbonate cannot be applied to all Ceara Rise sites to give reliable carbonate concentration changes. However, magnetic susceptibility, which reflects the terrigenous component of the sediments, has a high negative correlation to calcium carbonate concentration and is a reliable proxy for carbonate concentration variations between 5 and 10 Ma for Sites 925, 928, and 929. Thus, a depth transect of magnetic susceptibility-based carbonate concentrations was constructed for Sites 925, 928, and 929 between 5 and $10 \mathrm{Ma}$. These time series show that the depth gradient of carbonate concentration exhibited substantial changes in the middle and late Miocene.

A high resolution study of four representative intervals shows that the high frequency changes at shallow Site 925 can be attributed to variability in carbonate production and terrigenous dilution. The carbonate fraction is very well preserved and the measured fluxes are indicative of carbonate production in the euphotic zone. In contrast, sites 1000 to $1500 \mathrm{~m}$ deeper have a strong overprint of dissolution. During the late Miocene, there is a significant increase in carbonate production observed at Site 925, as compared with the Holocene. This increase in relatively shallow-water deposition of carbonate is associated with a shoaling of the CCD and substantially increased dissolution at depth. The pattern of shallow to deep fractionation of carbonate is observed globally at this time, and the increased NADW flow proposed by Berger et al. (1993) does not appear to be responsible for the change. Further work on benthic stable isotope data from shallow and deep sites, and between basins, will be useful in addressing the NADW hypothesis. Our future plans also include the use of stable isotope and high resolution biostratigraphy to help improve correlations between the shallow and deep Ceara Rise sites. With refined age models, orbital-scale changes in the depth gradients can be examined along with the distortion of the carbonate flux time series caused by dissolution.

\section{ACKNOWLEDGMENTS}

We thank a number of laboratory workers at Brown University who helped prepare and analyze the samples in this study, including Mel Waldorf, Jenna Cook, Mike Zani, Jane Donnelly, Julie Maurin, Genevieve Proctor, Andrew Long, Celia Day, Tyler Prell, and Shoji Takahashi. Special thanks to Bob Fifer for designing and assembling the automated carbonate rig, and to Bill Curry and Rindy Ostermann for sharing the design of the WHOI automated carbonate analyzer and their experience in running it. Terri King shared splits of her sam- ples from the 5- to 5.4-Ma time interval. We appreciate the time-consuming work in developing and distributing the orbitally tuned age models by Nick Shackleton, Terri King, and their staff. We thank Nick Shackleton for suggesting a method to normalize the coarse fraction. Thorough reviews by John Farrell and Chris Charles were helpful and appreciated. Technical support for this project was obtained by grants from JOI/USSAC (USSSP 154-20836b) and NSF/ OCE (OCE-9302496).

\section{REFERENCES}

Archer, D., 1991. Modeling the calcite lysocline. J. Geophys. Res., 96: 17037-17050.

Benjamin, M., Johnson, N.M., and Naeser, C.W., 1987. Recent rapid uplift in the Bolivian Andes: evidence from fission-track dating. Geology, 15:680-683.

Berger, W.H., Bonneau, M.-C., and Parker, F.L., 1982. Foraminifera on the deep-sea floor: lysocline and dissolution rate. Oceanol. Acta, 5:249-258.

Berger, W.H., Leckie, R.M., Janecek, T.R., Stax, R., Takayama, T., 1993. Neogene carbonate sedimentation on Ontong Java Plateau: Highlights and open questions. In Berger, W.H., Kroenke, L.W., Mayer, L.A., et al., Proc. ODP, Sci. Results., 130: College Station, TX (Ocean Drilling Program), 711-744.

Broecker, W.S., and Peng, T.-H., 1982. Tracers in the Sea:Palisades, NY (Lamont-Doherty Geol. Obs.).

Brummer, G.-J.A., and van Eijden, A.J.M., 1992. "Blue-ocean” paleoproductivity estimates from pelagic carbonate mass accumulation rates. Mar. Micropaleontol., 19:99-117.

Charles, C.D., and Fairbanks, R.G., 1992. Evidence from Southern Ocean sediments for the effect of North Atlantic deep-water flux on climate. Nature, 355: 416-419.

Curry, W.B., Duplessy, J.-C., Labeyrie, L.D., and Shackleton, N.J., 1988. Changes in the distribution of $\delta^{13} \mathrm{C}$ of deep water $\Sigma \mathrm{CO}_{2}$ between the last glaciation and the Holocene. Paleoceanography, 3:317-341.

Curry, W.B., and Lohmann, G.P., 1990. Reconstructing past particle fluxes in the tropical Atlantic Ocean. Paleoceanography, 5:487-505.

Curry, W.B., Shackleton, N.J., Richter, C., et al., 1995. Proc. ODP, Init. Repts., 154: College Station, TX (Ocean Drilling Program).

Dickens, G.R., and Owen, R.M., 1994. Late Miocene-early Pliocene manganese redirection in the central Indian Ocean: expansion of the intermediate water oxygen minimum zone. Paleoceanography, 9:169-181.

Emerson, S., and Bender, M., 1981. Carbon fluxes at the sediment-water interface of the deep-sea: calcium carbonate preservation. J. Mar. Res., 39:139-162.

Farrell, J.W., Raffi, I., Janecek, T.R., Murray, D.W., Levitan, M., Dadey, K.A., Emeis, K.-C., Lyle, M., Flores, J.-A., and Hovan, S., 1995. Late Neogene sedimentation patterns in the eastern equatorial Pacific Ocean. In Pisias, N.G., Mayer, L.A., Janecek, T.R., Palmer-Julson, A., and van Andel, T.H. (Eds.), Proc. ODP, Sci. Results, 138: College Station, TX (Ocean Drilling Program), 717-756.

Hagelberg, T.K., Pisias, N.G., Mayer, L.A., Shackleton, N.J., and Mix, A.C., 1995a. Spatial and temporal variability of late Neogene equatorial Pacific carbonate: Leg 138. In Pisias, N.G., Mayer, L.A., Janecek, T.R., PalmerJulson, A., and van Andel, T.H. (Eds.), Proc. ODP, Sci. Results, 138: College Station, TX (Ocean Drilling Program), 321-336.

Hagelberg, T.K., Pisias, N.G., Shackleton, N.J., Mix, A.C., and Harris, S., 1995b. Refinement of a high-resolution, continuous sedimentary section for studying equatorial Pacific Ocean paleoceanography, Leg 138. In Pisias, N.G., Mayer, L.A., Janecek, T.R., Palmer-Julson, A., and van Andel, T.H. (Eds.) Proc. ODP Sci. Results, 138: College Station, TX (Ocean Drilling Program), 31-46.

Haq, B.U., Hardenbol, J., and Vail, P.R., 1987. Chronology of fluctuating sea levels since the Triassic. Science, 235:1156-1167.

Herbert, T.D., and Mayer, L.A., 1991. Long climatic time series from sediment physical property measurements. J. Sediment. Petrol., 61:10891108

Honjo, S., Dymond, J., Collier, R., and Manganini, S.J., 1995. Export production of particles to the interior of the equatorial Pacific Ocean during the 1992 EqPac experiment. Deep-Sea Research II, 42:831-870.

Kroenke, L.W., Berger, W.H., Janecek, T.R., et al., 1991. Proc. ODP, Init. Repts., 130: College Station, TX (Ocean Drilling Program).

Lyle, M., 1992. Composition maps of surface sediments of the eastern tropical Pacific Ocean. In Mayer, L., Pisias, N., Janecek, T., et al., 1992. Proc. 
ODP, Init. Repts., 138 (Pt. 1): College Station, TX (Ocean Drilling Program), 101-115.

Murray, D.W., Farrell, J.W., and McKenna, V., 1995. Biogenic sedimentation at Site 847, eastern equatorial Pacific Ocean, during the past 3 m.y. In Pisias, N.G., Mayer, L.A., Janecek, T.R., Palmer-Julson, A., and van Andel, T.H. (Eds.), Proc. ODP, Sci. Results, 138: College Station, TX (Ocean Drilling Program), 429-459.

Oppo, D.W., and Fairbanks, R.G., 1987. Variability in the deep and intermediate water circulation of the Atlantic Ocean during the past 25,000 years: Northern Hemisphere modulation of the Southern Ocean. Earth and Planet. Sci. Lett., 86:1-15.

Ostermann, D.R., Karbott, D., and Curry, W.B., 1990. Automated system to measure carbonate concentration of sediments. WHOI Tech. Rept., 90103.

Peterson, L.C., and Backman, J., 1990. Late Cenozoic carbonate accumulation and the history of the carbonate compensation depth in the western equatorial Indian Ocean. In Duncan, R.A., Backman, J., and Peterson, L.C., et al., Proc. ODP, Sci. Results, 115: College Station, TX (Ocean Drilling Program), 467-507.

Peterson, L.C., Murray, D.W., Ehrmann, W.U., and Hempel, P., 1992. Cenozoic carbonate accumulation and compensation depth changes in the Indian Ocean. In Duncan, R.A., Rea, D.K., Kidd, R.B., von Rad, U., and Weissel, J.K. (Eds.), Synthesis of Results from Scientific Drilling in the Indian Ocean, Geophys. Monogr., Am. Geophys. Union, 70:311-333.

Peterson, L.C., and Prell, W.L., 1985. Carbonate dissolution in recent sediments of the eastern equatorial Indian Ocean: preservation patterns and carbonate loss above the lysocline. Mar. Geol., 64:259-290.

Shackleton, N.J., Crowhurst, S., Hagelberg, T., Pisias, N.G., and Schneider, D.A., 1995. A new late Neogene time scale: application to Leg 138 sites.
In Pisias, N.G., Mayer, L.A., Janecek, T.R., Palmer-Julson, A., and van Andel, T.H. (Eds.), Proc. ODP, Sci. Results, 138: College Station, TX (Ocean Drilling Program), 73-101.

Shipboard Scientific Party, 1995a. Leg 154 synthesis. In Curry, W.B., Shackleton, N.J., Richter, C., et al., Proc. ODP, Init. Repts., 154: College Station, TX (Ocean Drilling Program), 421-442.

Shipboard Scientific Party, 1995b. Site 925. In Curry, W.B., Shackleton, N.J., Richter, C., et al., Proc. ODP, Init. Repts., 154: College Station, TX (Ocean Drilling Program), 55-152.

Shipboard Scientific Party, 1995c. Site 929. In Curry, W.B., Shackleton, N.J., Richter, C., et al., Proc. ODP, Init. Repts., 154: College Station, TX (Ocean Drilling Program), 337-417.

Shipboard Scientific Party [ODP Leg 145], 1993. Paleoceanographic record of North Pacific quantified. Eos, 74:406-411.

Woodruff, F., and Savin, S.M., 1989. Miocene deepwater oceanography. Paleoceanogr., 4:87-140.

Wright, J.D., Miller, K.G., and Fairbanks, R.G., 1992. Early and middle Miocene stable isotopes: implications for deepwater circulation and climate. Paleoceanogr., 7:357-389.

Date of initial receipt: 5 December 1995

Date of acceptance: 16 August 1996

Ms 154SR-117 